\title{
LXIII. On radiation of heat and light from heated solid bodies
}

\section{J.T. Bottomley D.Sc. F.R.S.}

To cite this article: J.T. Bottomley D.Sc. F.R.S. (1902) LXIII. On radiation of heat and light from heated solid bodies, Philosophical Magazine Series 6, 4:23, 560-568

To link to this article: http://dx.doi.org/10.1080/14786440209462880

曲 Published online: 15 Apr 2009.

Submit your article to this journal $\pi$

Q View related articles $\sqsubset$ 
At ordinary temperatures its value is given by

$$
\frac{e}{\mathrm{E}}=(3 \check{5}+3 \cdot 9 n)(\mathrm{H}-4500) 10^{-8},
$$

where $n=$ frequency, and $\mathrm{H}=$ field-strength.

II. The angle of lag of the bismuth E.M.F. behind the current in the bismuth

(a) varies with frequency;

$(b)$ is independent of temperature and field-strength.

Owens College, Manchester.

LXIII. On Radiation of Heat and Light from Heated Solia Bodies. By J. T. BoT'OMLeY, D.Sc., F.R.S.*

[Plates V. \& VI.]

THE following paper describes a further instalment of 1 experiments on radiation of beat and light from heated solid bodies, a subject to which I have given attention for a considerable number of years. It is a difficult subject, and it has only been at times that I have been able to make progress in the prosecution of the inquiry. I have treated it from first to last in a purely experimental way. I do not feel that there exists at present suflicient experimental information to admit of anything like a complete theory. Indeed the information which we possess is of the scantiest character.

My aim has been to determine directly the quantity of heat lost from a given surface under given conditions; and the method by which I have carried out my experiments bas been to put the radiating body into a vacuum as complete as I can obtain, and then to measure the energy lost from it in a Fiven time, noting the circumstances. By adopting this plan $I$ avoid determinations of the value of heat-receptors, such as sooted bolometers or sooted thermojunctions; and I obtain results in absolute measure.

In a paper published in the Transactions of the Royal Society as far back as 1887 I showed that it is possible to obtain with the Sprengel-pump a vacuum so good that the effect of convection on loss of heat from a hot body, in so far as that loss is caused by non-condensable gases, ceases to be of importance in comparison with loss due to pure radiation; in fact, that increasing the vacuum, as

* Communicated by Lord Kelvin. 
indicated by the McLeod gauge, beyond a certain point makes no difference to the amount of heat lost.

It is not certain that the results would be quite the same could all the mercury vapour, which must undoubtedly exist in the vacuum-chamber, be removed; and this is a question which still requires investigation. Other condensable gases, such as vapour of phosphorus (given off from the drying apparatus) also need consideration. The last mentioned gas I have, however, recently done away with, I hope completely, by using phosphorus pentoxide which I have specially prepared for the purpose.

I only desire at present to call attention to one particular part of the general investigation.

In 1887, together with Mr. Mortimer Evans, I pointed out the marked difference in emissivity between a polished metallic-like surface and a dull sooted surface. I think it is now generally admitted $*$ that such a difference does really exist, but at the time my conclusions were controverted. For example, in his book on 'Practical Electrical Measurement,' Mr. Swinburne has the following passage:-

"Mr. Bottomley read a paper at the British Association in 1887 giving an account of some experiments as to colour and temperature. His conclusions are opposed to those generally accepted by physicists, and before they can be accepted a great deal more evidence must be given. Mr. Bottomley, apparently, regards his paper as a mere first notice, and intends to continue his important experiments. At present it may be suggested that his arguments as to Mr. Evans's experiments are open to criticism. The resistance of a lampcarbon varies with the temperature in accordance with no evidont law, and the colour of the light and radiation depend on the surface temperature of the whole carbon. A carbon of high emissivity would need a higher internal temperature to preserve a given surface temperature than one of low emissivity. The same reasoning applies to two platinum wires, one of which is blackened. Besides, Mr. Bottomley does not state whether the lampblacked wire was heated to incandescence before the tube was sealed off the pump †; and if it were not, it would be coated with hydrocarbons,

* [Note added July 31st, 1902.] In the discussion which followed this paper at the meeting of the British Association, September 1901, one of the speakers expressed the view that incandescent-lamp makers do not find any difference between flashed and unflashed filaments. I venture to thirik, however, that this is incorrect. Incandescent-lamp makers are naturally reticent as to their experience, but I believe that all first-class makers are now fully alive to a difference in economy between a brightly flashed filament and a dull unflashed filament.

+ The tube is never sealed off the pump. The pump is kept working the whole time to remove occluded gases given of from the platinum. 
which would spoil the vacuum in that tuhe. It is, no doubt, unlikely that one so careful as Mr. Bottomley would make such mistakes; but, on the other hand, his results are so opposed to those of others that they may be disregarded for the present, and the law that efficiency is a test of surfuce-temperature, and colour is a test of both, may be taken as true."

I have alwars desired to examine further the question here referred to, and to come to definite conclusions on the subject, but it is only recently that $I$ have been able to arrange for a set of perfectly conclusive experiments.

The apparatus which I use is shown in Pl. V., which will serve to explain the details.

The radiating body which $I$ bave used recently has been a thin platinum strip heated by an electric current. The strip was rolled for the purpose by Messrs. Johnson and Mathey, to whom I beg to express my thanks for the great trouble they have taken in order to provide me with perfectly uniform material. The way in which it is mounted is shown in the figures. The strip $\mathrm{AB}$ is held stretched between two spiral springs in a glass tube: the outer ends of the spiral springs terminate in loops, and two pieces of copper rod are passed into the tubes $\mathrm{CC}$ and $\mathrm{C}^{\prime} \mathrm{C}^{\prime}$ so that the springs pull on these rods. These rods pass down through long narrow side tubes into mercury cups, and by means of these the electric current which heats the platinum strip is passed into it.

At the points EE (see elevation) of the platinum strip fine platinum wires are attached by welding, and they are brought out through the sides of the glass envelope. These serve as potential electrodes; and it is to keep the platinum strip $\mathrm{AB}$ in the middle of the tube, and to avoid pulling unduly on the potential electrodes that the two spiral springs, one at each end of the tube, are introduced.

Two exactly similar tubes are employed, as shown in Pl. V. (plan). They are connected together at each end, as shown; and by means of a branch tube, attached to one of the two end tubes and connected to a Sprengel-pump, the air is withdrawn from both tubes at the same time. By this arrangement it is provided that the vacuum in the two experimental tubes shall be at all times precisely the same.

In one of the tubes the platinum strip is brightly polished and perfectly smooth, just as it came from the makers' hands. The other tube contains a platinum strip of exactly the same length between the points $\mathrm{EE}$, and cut from the same hank, but with the surface covered with an exceedingly fine coating of lampblack.

The arrangements for drying the vacuum consist in (1) a 
flask of phosphorus pentoxide attached to the pump by a wide side tube, and so arranged that it does not choke the connexion between the pump and the apparatus; (2) four pockets, two on each experimenting tube, as shown in sketch, each one containing phosphorus pentoxide. These pockets are short side tubes of the same diameter as the main tubes, and they allow free access for diffusion of the water-vapour into the drying material.

This method of arranging the drying-tubes seems to me to be far better than the usual plan of putting a good long column of drying material between a pump and the apparatus to be exhausted. The effect of the latter is only to dry the gas that is pumped away, not to dry the gas remaining in the experimental apparatus, except by diffusion. Moreover, such an arrangement must very seriously retard the process of exhaustion at very low pressures, by choking the tube.

The vacuum is measured by a modification of the McLeod gauge attached to the second of the end tubes mentioned above (see Pl.V.), so that the experimenting tubes are between the pump and the gauge. By this arrangement it may be safely assumed that the vacuum in the experimenting tubes is at least as good as the vacuum in the gauge, especially as the gauge was so made as to allow a wide tube connexion with the apparatus, in order to assist diffusion and prevent its readings from lagging behind what they should be.

The electrical connexions, by means of which the currents of electricity, which heat the strips, are passed into them and are measured, will be easily understood from the figures (Pl. V.). The current is supplied by a storage-battery of ten cells. There are two separate circuits, one for each strip. The current sent into each is regulated partly by the number of cells, and partly by a rheostat in circuit; and an amperemeter in each circuit measures the current passing.

A voltmeter can be applied to the working part of either strip by means of the potential electrodes, $\mathrm{EE}, \mathrm{E}^{\prime} \mathrm{E}^{\prime}$, and the double-pole change-over switch indicated in the figure.

It will be seen from the elevation on Pl. $\mathrm{V}$. that the electrodes, $\mathrm{EE}$, are attached at some distance from the ends of the strip $\mathrm{AB}$. This is to avoid disturbance from the cooling effect of the end attachments. It is the portion $\mathrm{EE}$ which $\mathrm{I}$ call the working part of the strip.

In a very interesting paper by $\mathrm{W}$. H. Weber, published in the Annalen der Physik und Chemie, vol. xxxii. p. 256, a paper which I think has scarcely received the attention which it deserves, the author traces from the very commencement the production of light by a heated solid body. He 
shows that a solid body first becomes luminous at a very much lower temperature than $535^{\circ} \mathrm{C}$., which was given by Draper as the temperature of the lowest visible red heat. Weber found traces of luminosity at a temperature as low as $391^{\circ}$ (. for platinum, and about $378^{\circ} \mathrm{C}$. for iron.

He also describes very carefully, and in an extremely interesting manner, the dawn of a dusky gray light at these temperatures, and its transformation at higher temperatures into the light of low red heat, and subsequently into bright red light and white light.

Following Weber I have commenced by bringing up the platinum strips to the very lowest temperatures at which luminescence could be perceived, and 1 then measured the electrical power required to maintain the temperature of each strip, one of them polished and the other covered with lampblack. This being done, I passed on to very dull red, then to dull red, and subsequently to cherry-red, and to a white heat; and in each case I made similar measurements with the voltmeter and amperemeters, to ascertain the power in watts required in each case. The two strips were matched as to light-giving quality as closely as possible.

After some practice my assistant, Mr. W. T. Evans, whose accuracy I cannot sufficiently praise, attained great skill in matching the pairs of strips. The results of our experiments are shown in the following table (p. 565) and in the corresponding curves 1,2 , and 3 , Plate VI.

Column 2 of the table describes the condition of the strips. The specification gray light, dull red, \&c. is purely arbitrary, and mainly indicates the opinion of the experimenters, Mr. Evans and myself, as to the light-giving condition of the surface. The gray light referred to in experiments 1 and 2 is the colourless light of Weber; though in our experiments, at the lowest point of temperature at which he observed the beginnings of light, we could not see anything *. The nearly white light of experiment 13 is not nearly so white as the light produced from an incandescent electric lamp. It has been explained that the two strips were matched in appearance in our experiments, and Column 9 shows approximately the temperature of each strip, inferred from the resistance of the strip which is given in Column 6. The resistance is easily obtained as the ratio of the potential-difference to the current. The current in amperes passing through each strip is shown in Column 4, and the potential-difference in volts between the points EE, in each strip, is shown in Column 5.

By multiplying together the amperes and the volts and dividing by JS, the product of Joule's equivalent $\mathrm{J}$, and S

* Doubtless through want of practice. 
the surface, in square centimetres, of the strip between the potential leads $\mathrm{EE}$, the absolute amount of energy lost by the strip per square centimetre per second is found. This is equal to $\mathrm{AV} / 4 \cdot 2 \mathrm{~S}$, and is shown for all the experiments in Column 10. The figures in Column 10 represent the number of gramme-water-degree-centigrade-units of radiant energy lost per second from each square centimetre of surface of the strips.

Table of Results.

\begin{tabular}{|c|c|c|c|c|c|c|c|c|c|}
\hline $\begin{array}{l}\text { No. of } \\
\text { Expt. }\end{array}$ & Condition. & Strip. & Awps. & Volts. & Ohms. & Watts. & $\begin{array}{l}\text { Watt- } \\
\text { ratio. }\end{array}$ & Temp. & $\mathrm{AV} / \mathrm{JS}$. \\
\hline 1. & Gray light. & $\begin{array}{l}\text { Bright. } \\
\text { Black. }\end{array}$ & $\begin{array}{l}1 \cdot 9 \\
5 \cdot 35\end{array}$ & $\begin{array}{l}1 \cdot 01 \\
2 \cdot 81\end{array}$ & $\begin{array}{l}0.522 \\
0.525\end{array}$ & $\begin{array}{c}1 \cdot 9 \cdot 22 \\
15 \cdot 09\end{array}$ & $7 \cdot 85$ & $\begin{array}{l}435^{\circ} \\
452\end{array}$ & $\begin{array}{l}0.0417 \\
0.327\end{array}$ \\
\hline 2. & $"$ & $\begin{array}{l}\text { Bright. } \\
\text { Black. }\end{array}$ & $\begin{array}{l}2 \cdot 13 \\
5 \cdot 9\end{array}$ & $\begin{array}{l}1 \cdot 175 \\
3 \cdot 23\end{array}$ & $\begin{array}{l}0.552 \\
0.547\end{array}$ & $\begin{array}{c}2 \cdot 5 \\
19 \cdot 05\end{array}$ & $7 \cdot 62$ & $\begin{array}{l}465 \\
487\end{array}$ & $\begin{array}{l}0.0543 \\
0 \cdot 414\end{array}$ \\
\hline 3. \{ & $\left\{\begin{array}{c}\text { Very dull } \\
\text { red. }\end{array}\right\}$ & $\begin{array}{l}\text { Bright. } \\
\text { Blank. }\end{array}$ & $\begin{array}{l}2 \cdot 31 \\
6 \cdot 2\end{array}$ & $\begin{array}{l}1 \cdot 32 \\
3 \cdot 45\end{array}$ & $\begin{array}{l}0.572 \\
0.557\end{array}$ & $\begin{array}{l}3 \cdot 05 \\
21 \cdot 4\end{array}$ & 7.02 & $\begin{array}{l}495 \\
503\end{array}$ & $\begin{array}{l}0.0662 \\
0.465\end{array}$ \\
\hline 4. & $"$ & $\begin{array}{l}\text { Bright. } \\
\text { Black. }\end{array}$ & $\begin{array}{l}2 \cdot 34 \\
6 \cdot 25\end{array}$ & $\begin{array}{l}1 \cdot 43 \\
3 \cdot 7\end{array}$ & $\begin{array}{l}0.611 \\
0.592\end{array}$ & $\begin{array}{l}3 \cdot 31 \\
23 \cdot 1\end{array}$ & 698 & $\begin{array}{l}550 \\
560\end{array}$ & $\begin{array}{l}0 \cdot 0727 \\
0.50 !\end{array}$ \\
\hline 5. & Dull red. & $\begin{array}{l}\text { Bright. } \\
\text { Black. }\end{array}$ & $\begin{array}{l}2 \cdot 8 \\
7 \cdot 2\end{array}$ & $\begin{array}{l}1 \cdot 74 \\
4 \cdot 32\end{array}$ & $\begin{array}{l}0.622 \\
0.600\end{array}$ & $\begin{array}{l}4 \cdot 87 \\
31 \cdot 1\end{array}$ & 6.53 & $\begin{array}{l}573 \\
573\end{array}$ & $\begin{array}{l}0 \cdot 106 \\
0.676\end{array}$ \\
\hline 6. & $"$ & $\begin{array}{l}\text { Bright. } \\
\text { Black. }\end{array}$ & $\begin{array}{l}3 \cdot 04 \\
7 \cdot 7\end{array}$ & $\begin{array}{l}1 \cdot 975 \\
4.77\end{array}$ & $\begin{array}{c}0 \cdot 650 \\
0 \cdot 620\end{array}$ & $\begin{array}{r}6 \cdot 0 \\
36 \cdot 8\end{array}$ & $6 \cdot 13$ & $\begin{array}{l}613 \\
607\end{array}$ & $\begin{array}{l}0 \cdot 1302 \\
0 \cdot 799\end{array}$ \\
\hline 7. & $"$ & $\begin{array}{l}\text { Bright. } \\
\text { Black. }\end{array}$ & $\begin{array}{l}3 \cdot 2 \\
8 \cdot 0\end{array}$ & $\begin{array}{l}2 \cdot 1 \\
5 \cdot 05\end{array}$ & $\begin{array}{l}0.656 \\
0.632\end{array}$ & $\begin{array}{l}6.72 \\
40.4\end{array}$ & 6.02 & $\begin{array}{l}623 \\
625\end{array}$ & $\begin{array}{l}0.146 \\
0.877\end{array}$ \\
\hline 8. & Fair red. & $\begin{array}{l}\text { Bright. } \\
\text { Black. }\end{array}$ & $\begin{array}{l}3.5 \\
8 \cdot 5\end{array}$ & $\begin{array}{l}2 \cdot 37 \\
5 \cdot 47\end{array}$ & $\begin{array}{l}0.677 \\
0.644\end{array}$ & $\begin{array}{r}8 \cdot 3 \\
46 \cdot 5\end{array}$ & $5 \cdot 6$ & $\begin{array}{l}655 \\
643\end{array}$ & $\begin{array}{l}0 \cdot 180 \\
1 \cdot 01\end{array}$ \\
\hline 9. & Good red. & $\begin{array}{l}\text { Brightt. } \\
\text { Black. }\end{array}$ & $\begin{array}{l}4 \cdot 0 \\
9 \cdot 45\end{array}$ & $\begin{array}{l}2 \cdot 79 \\
6 \cdot 32\end{array}$ & $\begin{array}{l}0.697 \\
0.670\end{array}$ & $\begin{array}{l}11 \cdot 15 \\
59 \cdot 7\end{array}$ & $5 \cdot 36$ & $\begin{array}{l}685 \\
685\end{array}$ & $\begin{array}{l}0.242 \\
1.296\end{array}$ \\
\hline 10. & Bright red. & $\begin{array}{l}\text { Bright. } \\
\text { Black. }\end{array}$ & $\begin{array}{c}4 \cdot 62 \\
10 \cdot 4\end{array}$ & $\begin{array}{l}3 \cdot 35 \\
7 \cdot 24\end{array}$ & $\begin{array}{l}0.724 \\
0.696\end{array}$ & $\begin{array}{l}15 \cdot 45 \\
75 \cdot 2\end{array}$ & $4 \cdot 87$ & $\begin{array}{l}727 \\
727\end{array}$ & $\begin{array}{l}0.335 \\
1.632\end{array}$ \\
\hline 11. & $\left.\begin{array}{c}\begin{array}{c}\text { Very bright } \\
\text { red. }\end{array}\end{array}\right\}$ & $\begin{array}{l}\text { Bright. } \\
\text { Black. }\end{array}$ & $\begin{array}{r}5 \cdot 3 \\
11 \cdot 6\end{array}$ & $\begin{array}{l}4 \cdot 1 \\
8 \cdot 52\end{array}$ & $\begin{array}{l}0773 \\
0.735\end{array}$ & $\begin{array}{l}21 \cdot 7 \\
98 \cdot 9\end{array}$ & $4: 56$ & $\begin{array}{l}800 \\
793\end{array}$ & $\begin{array}{l}0 \cdot 472 \\
2 \cdot 147\end{array}$ \\
\hline 12. & $"$ & $\begin{array}{l}\text { Bright. } \\
\text { Black. }\end{array}$ & $\begin{array}{r}5 \cdot 99 \\
12 \cdot 75\end{array}$ & $\begin{array}{l}48 \\
9.85\end{array}$ & $\begin{array}{l}0.801 \\
0.772\end{array}$ & $\begin{array}{r}28 \cdot 7 \\
125.6\end{array}$ & 438 & $\begin{array}{l}843 \\
848\end{array}$ & $\begin{array}{l}0623 \\
273\end{array}$ \\
\hline 13. & Nearly white. & $\begin{array}{l}\text { Bright. } \\
\text { Black. }\end{array}$ & $\begin{array}{r}6 \cdot 4 \\
13 \cdot 2\end{array}$ & $\begin{array}{c}5 \cdot 35 \\
10 \cdot 5\end{array}$ & $\begin{array}{l}0.836 \\
0.796\end{array}$ & $\begin{array}{r}34 \cdot 2 \\
138 \cdot 7\end{array}$ & $4 \cdot 06$ & $\begin{array}{l}898 \\
891\end{array}$ & $\begin{array}{l}0742 \\
301\end{array}$ \\
\hline
\end{tabular}

Column 7 gives the power in watts supplied to each strip, i. e. the product of the current into the P.D. between the points EE. Column 8 gives the ratio of the watts used by the dull strip to the watts used by the bright one, both being matched in appearance, and both being practically at the same temperature, as is shown by the numbered experimental points on No. 1 curve lying so nearly on the same ordinates as the corresponding points on No. 2 curve. 
Curves No. 1 and No. 2 were plotted from the results of measurements of resistance and temperature made on the two strips when dismounted after the radiation experiments. The resistance numbers of Column 6 were then marked on these curves, and the corresponding abscissæ gave at once the temperatures shown in Column 9.

It will be seen by the divergence of Curves 1 and 2 that the increase of resistance with temperature in the dull strip is very slightly lower than that in the bright strip. This is probably due to the conducting power of the thin filament of lampblack which covered the strip. The lampblack would have a slight effect in reducing the resistance of the strip, and it would also have an effect, of minor order, in reducing the rate of increase with temperature of resistance of the coated strip.

Curve 3 of the figure shows the watt-ratio for the two strips at the mean of the temperatures given in Column 9 .

It appears from the table and the curves that the blackened strip consumes energy at a greater rate than the bright strip when the two are at the same temperature, and that at each point when the strips are giving off an equal amount of light the blackened strip is using much more energy per second than the polished strip.

It seems also that the ratio between the power used by the two strips is much higher at the commencement of luminescence than at a brighter heat; and it may be that a point would be reached at a very high temperature where this ratio might become constant, or else that at an extremely high temperature the power required to supply the blackened and the bright strips might not be verry different in amount.

The platinum strips were used in order to give a better comparison by eye than can be got from thin wires of the same electric carrying capacity, but it has been very difficult to obtain platinum strips which would not break at a very moderate temperature. I have tried commercial platinum strip, and also strip of perfectly pure platinum; latterly I tried strip containing 10 per cent. of iridium in order to harden it, but none has been as successful as I hoped. It has been very disappointing that in every case one or other of the strips broke, and my experiments have been stopped before I could reach a really very high temperature. 'The breaking of the strips is not to be attributed to an over great tension in the spiral springs. The amount of pull in the spiral springs was only so great as to take up the slack due to the expansion of the platinum with heat. I have a very 
strong feeling, though I am not quite able to prove the assertion, that the platinum wires become excessively brittle, or as it is sometimes called with respect to brass wire, "rotten," during the long process of heating and pumping which is necessary, as a preliminary to the experiments, in order to remove from the platinum the gases occluded in it *.

In a paper which I published in 1900 along with Prof. J. C. Beattie (Royal Society Proceedings, March 1900)†, the radiation from polished and blackened platinum wires was determined in a somewhit different way. The apparatus used was practically the same as that which I have just now described, but instead of comparing the energy lost by the wires when they presented the same appearance to the eye as to light-giving quality, the comparison was made between pairs of wires at the same temperature, the temperature being known by the resistance of the $\mathrm{n}$ ires. Three pairs of wires having different diameters were used in these experiments, and it was shown that the thermal energy lost by the sooted wire wias from four to five times as great as that lost by the polished wire, the two being, as 1 have said, at the sane temperature.

In one respect the determinations, an account of which is given in the present paper, and in the paper by Dr. Beattie and myselt', are not perfectly satisfactory. We have not been able to take account in a proper way of the temperature of the enclosing envelope. In order to be able to see the condition of the wires, and in particular to observe their appearance when they became luminous, glass envelopes were used in these experiments; and owing to the nature of the arrangements and the method of experimenting it was not found possible to immerse the glass envelopes in a cooling bath. Consequently, the glass became more or less heated during the experiment, and the heating was unequal in the cases of the bright wire and the sooted wire. It has already been pointed out (Phil. Trans. A, 1887, p. 450) that the

\footnotetext{
* [Footnote added Oct 18th, 1902.] In a paper by Dr. Hartley (Phil. Mag. July 1902) it is mentioned that the preseace of curbon and phosphorus render platinum brittle. It is quite possible that some traces of phosphorus vapour may still find their way into my tubes, although $I$ have made the greatest effort, by preparing the phosphorns pentoxide which I use with every care and every precaution I can think of, to avoid this contamination, of which I have always had a fear. My phosphorus pentoxide, the best I could buy, was most carefully redistilled, by myself, in a current of oxygen. The distillation was carried on in special tubes of hard glass, constructed by Mr. Evans, following the method of Shenstone. + Phil. Mag. June 1900, pp. 543-550.
} 
proportions in wbich the radiation of longer period and shorter period are present in the total radiation depends on the radiating surface, other things being the same. In the case of the sooted wire, the quantity of long-period radiation is, in proportion, far in excess of that proceeding from a bright metallic polished surface. Consequently, with the same total electric energy supplied to both wires, the glass tube containing the sooted wire becomes very much hotter than the tube containing the bright wire.

It has also been pointed out that with a substance like glass, conducting badly and somewhat diathermanous, it is impossible to tell how much heat is returned to the radiating wire from the interior skin of the tube, which no doubt rises to a high temperature during the experiment. To a certain extent, therefore, the results which we have recently obtained must be considered as not strictly comparable with those formerly obtained, in which a metallic envelope cooled with water was used.

The absolute value of the radiation observed ought to be somewhat lower in amount than would have been found har the enclosing envelope been of metal properly kept cool, and the disturbance from this cause must have been relatively greater in the case of the dull than in the case of the bright wire.

I cannot conclude without expressing my warmest thanks to my assistant, Mr. Evans, whose aid has been invaluable. Without the help which he has given me the experiments could not have been carried out at all. The investigation is still in progress, indeed, the present paper must be regarded as a description of preliminary trials; I hope before long, however, to obtain further results in the same direction of considerable interest. The temperatures shown on the curves and in the tables have been obtained partly by direct experiment and partly by using the results of other experimenters who have given comparisons between platinum resistances and temperatures. They must only be regarded as approximations, and may possibly require to be corrected. The amount of the correction cannot, however, alter the general conclusion that the polished surface is much more economical for the production of light than the sooted surface; and that as far as our experiments have gone, the polished platinum surface and the sooted surtace are practically at the same temperature when they present a similar appearance to the eye. 
Phil. Mag. Ser. 6, Vol, 4, Pl. V.
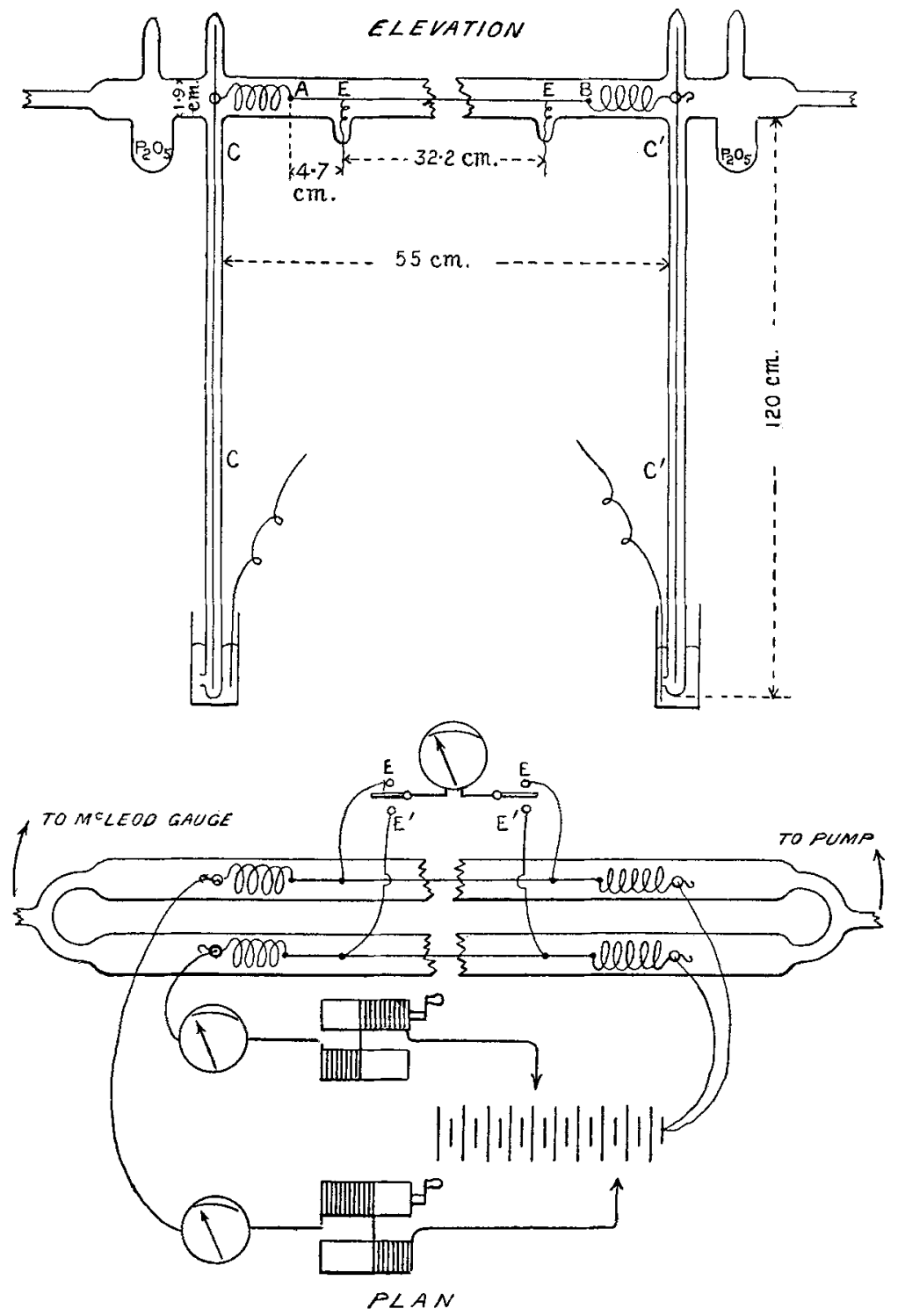
Phil. Mag. Ser. 6, Vol. 4, Pl. VI.

Watt-Ratio.

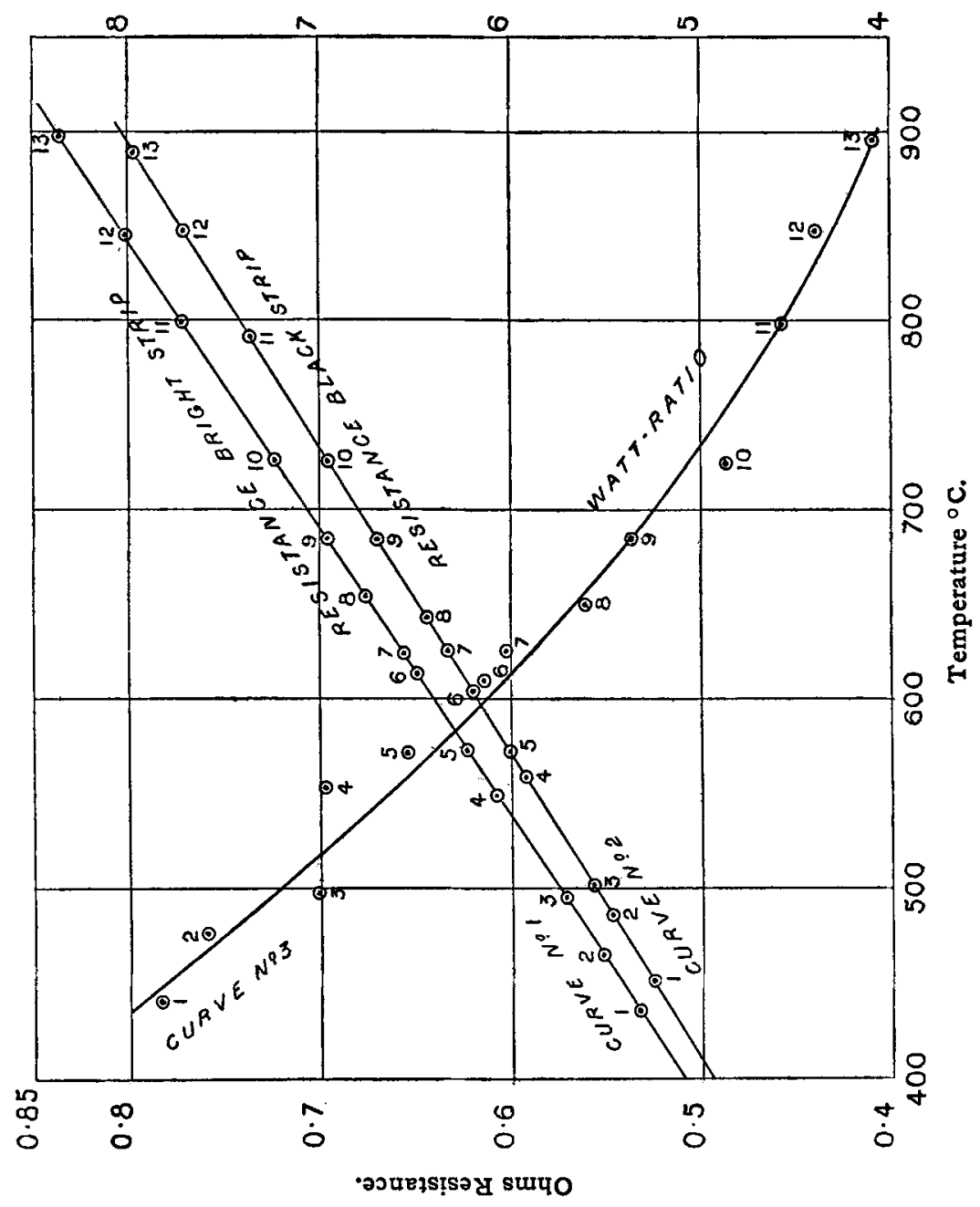

